\title{
SOME LIMITATIONS ON THE CONTROLLABILITY OF THE REFERENT IN TURKISH DEMONSTRATIVES
}

\section{TÜRKÇE İŞARET SÖZCÜKLERINNDE GÖNDERGENIN KONTROL EDİLEBİLIRLIĞİ ÜZERINDEKİ BAZI KISITLAMALAR}

Metin BALPINAR*

\begin{abstract}
More recent linguistic works on Turkish demonstratives have turned their attention to the concept of controllability which is one of the pragmatico-semantic parameters and which conditions the occurrence of the text-dependent (non-anaphoric) usages of bu and $o$ in the verbal text. In this study, it is shown that Turkish has a phenomenon which cannot be purely explained in terms of this concept, and it is argued that (i) there are some limiting conditions determining the distribution of the non-anaphoric demonstratives other than this parameter in Turkish demonstrative use, (ii) the interchangeability between the antecedent noun and the co-referential noun is one of the crucial factors that are operative in the selection of the appropriate usages of the non-anaphoric bu and o, (iii) on the situation where the intended referent is within the controllable domain of the speaker, 'bu' is used to refer to it if the co-referential noun semantically contains the antecedent noun, and ' $o$ ' is used to refer to it if the antecedent noun contains the co-referential noun, (iv) on the situation where the referent is not within the controllable domain of the speaker, ' $O$ ' refers to it regardless of whether the co-referential noun semantically contains the antecedent noun or not, (v) time is a secondary factor conditioning whether the intended referent is within the controllable domain of the speaker or not.
\end{abstract}

Keywords

Turkish, demonstratives, the non-anaphoric use, controllable domain, antecedent noun, coreferential noun, time

$\ddot{O} z$

Türkiye Türkçesindeki işaret sözcükleri üzerine yapılan yakın zamandaki çalışmalar, edimsel ve anlamsal değiştirgenlerden biri olan, bu ve o sözcüklerinin metne bă̆lı (artgönderimsel olmayan) kullanımlarını belli bir şarta bağlayan kontrol edilebilirlik kavramına odaklanmıştır. Bu çalışmada, Türkçenin, bu kavram ile tamamen açıklanamayan bir olguya sahip olduğu gösterilerek şu konulara vurgu yapılacaktır: (i) Türkçe işaret sözcüklerinin kullanımında, kontrol edilebilirlik kavramı dışında, artgönderimsel olmayan işaret sözcüklerinin dağılımını belirleyen bazı sınırlandırıcı koşullar bulunmaktadır, (ii) öncül ad ve eşgönderimsel adın birbiriyle değiştirilebilme özelliği, bu ve o'nun artgönderimsel olmayan kullanımların belirlemedeki en önemli etmenlerden biridir, (iii) göndergenin konuşucunun kontrol edilebilir alanı içinde olduğu durumlarda; eğer eşgönderimsel ad anlamsal

Dr. Öğr. Üyesi, Burdur Mehmet Akif Ersoy Üniversitesi, Doğu Dilleri ve Edebiyatları Bölümü, mbalpinar@mehmetakif.edu.tr, http://orcid.org/0000-0003-0998-2963 
olarak öncül adı kapsıyorsa 'bu', eğer öncül ad anlamsal olarak eşgönderimsel adı kapsıyorsa 'o' işaret sözcü̈̆̈̈ sözkonusu göndergeyi işaretler, (iv) göndergenin konuşucunun kontrol edilebilir alanı dışında oldŭ̆u durumlarda, eşgönderimsel adın öncül adı anlamsal olarak kapsayıp kapsamadığına bakılmaksızın 'o' işaret sözcüğ̈̈ göndergeyi işaretlemek için kullanılır, (v) zaman, işaretlenmek istenen göndergenin konuşucunun kontrol edilebilir alanı içinde olup olmadığını belirleyen ikincil bir etmendir.

\section{Anahtar Kelimeler}

Türkçe, işaret sözcükleri, artgönderimsel olmayan kullanım, kontrol edilebilir alan, öncül ad, eşgönderimsel ad, zaman 


\section{INTRODUCTION}

Modern Turkish has three demonstratives: $b u$ 'this', şu 'this/that', and $o$ 'that'. In addition, there are another set of forms that are morphologically associated with these demonstrative forms (Bastuji 1976; Gencan 2001; Kinsui et al. 2002; Göksel-Kerslake 2005; Hayasi 1985, 1989, 2008, 2009, 2014): bura/burası 'here', şura/şurası 'here/over there', ora/orası 'there' that refer to a location; böyle 'in this way', şöyle 'in that way', öyle 'in that (other) way' that refer to a situation; bunca 'so much, this much', şunca 'this/that much', onca 'that much' that denote situation or quantity. ${ }^{1}$ This is illustrated in Table $1 .{ }^{2}$

Table 1. Demonstratives in modern Turkish

\begin{tabular}{ccccc}
\hline & \multicolumn{3}{c}{ denotatum types } & \\
\cline { 2 - 4 } demonstrative roots & object/person & location & quantity & situation \\
\hline$b u-$ & $b u$ & bura/burası & bunca & böyle \\
$s ̧ u-$ & $s ̧ u$ & şura/şurası & şunca & şöyle \\
$o-$ & $o$ & ora/orası & onca & öyle \\
\hline
\end{tabular}

Among them, the monomorphemic forms $b u$, şu, and $o$ have all characteristics of the noun modifiers and independent pronouns; bunca, şunca, and onca are used as noun modifiers (demonstrative adjectives); bura/burası, şura/şurası, and ora/orası function as independent pronouns (demonstrative pronouns); böyle, şöyle, and öyle serve as verb modifiers (demonstrative adverbs) or noun modifiers in a different syntactic context. All demonstratives other than the demonstrative adjectives and adverbs may have case and number features.

In the previous grammatical works on Turkish, the appropriate usages of these demonstratives are accounted for the concept of relative distance between the referent and the deictic center (i.e. the speaker's location): $b u$ refers to objects close to the speaker, şu a little away from the speaker, and $o$ away from the speaker (Ergin 1958; Swift 1963; Lewis 1967; Iinuma 1995; Kornfilt 1997; Gencan 2001; Banguoğlu 2004; Korkmaz 2009). Besides, some accounts (Jansky 1943; Peters 1947) involve the additional notion visibility except for relative distance, i.e. $b u$ is used to refer to objects that are in proximity to the speaker, şu is used to refer to visible objects at mid-distance to the speaker, and $o$ is used to refer to invisible objects that are located at far distance from the speaker.

In challenging these past accounts, Underhill (1976), Hayasi (1985, 1989), Özyürek (1998), provide a more comprehensive explanation regarding the usages of $b u$, şu, and $o$. Underhill (1976) points out that the usage of şu can be associated with the notion of deictic gesture while the usage of $b u / o$ cannot. Regarding the distiction between $b u$ and $o$, Underhill reports that $b u$ refers to the proximal objects and $o$ refers to the distal objects with respect to the deictic center. Hayasi $(1985,1989)$ proposes that bu/o occurs when the entity is already introduced into the discourse 3 while şu occurs when the referent is not introduced into the discourse. According to

1 English translations of $b u, s ̧ u, o$ and their derivatives were added to show the analogy between the demonstratives in English and Turkish.

2 Note that there is one other demonstrative form which has the reinforced meaning of both şu 'this/that' and $o$ 'that': Şol. This form is essentially formed by combining the words $u s ̧$ 'here/because' and $o l$ 'that'. Since it is no longer used in modern Turkish, it is not given place in Table 1.

$3 \quad$ Hayasi (1985: 57) defines the notion of discourse as mutual knowledge between the speaker and the hearer concerning a situation and a context. In the present study, this notion is understood as verbal text that is formed by the speaker 
Hayasi, the parameter that conditions the appropriate usages of $b u$ and $o$ is a spatiotemporal/psychological distance: $b u$ indicates the objects close to the speaker and $o$ denotes the objects away from the speaker. Özyürek (1998) proposes that the medial term şu is used when the intended referent is not within the hearer's visual attention, and both the proximal term $b u$ and the distal term $o$ are used when the referent is already within the hearer's visual attention.

In recent years, several studies which aim at shedding light on syntactic, semantic, and pragmatic properties of modern Turkish demonstratives have been conducted (Balpinar 2011, 2012, 2014, 2019). In order to provide a unified explanation for the various usages, Balpinar roughly divides the demonstrative uses into the exophoric use and the endophoric use on the basis of his analysis. The exophoric use is a demonstrative use which involves pointing to entities that do not occur as a linguistic expression in the discourse (i.e. the entities that is not textualized) and the endophoric use is a demonstrative use which involves reference to entities that occur as a linguistic expression in the discourse (i.e. the entities that is textualized). Moreover, he subdivides the endophoric use into the non-anaphoric use, which involves re-occurrence of the antecedent noun in the subsequent sentence, and the anaphoric use, which does not involve reoccurrence of the antecedent noun in the subsequent sentence. In these analyses, it is shown that in the exophoric use, the notions of the speaker's space and recognition by the hearer condition the appropriate usages of the demonstratives, and in the non-anaphoric and anaphoric uses, the concepts of controllable domain and open sentence are operative in determining the distribution of the endophoric forms, respectively.

In the present study, it will be focused on the non-anaphoric usages of $b u$ and $o$, and shown that Turkish demonstratives have a phenomenon which solely cannot be explained by the concept of controllable domain, and proposed that the replaceability between the antecedent noun and the co-referential noun in the subsequent sentence also plays a major role in dealing with the phenomenon, and time is a secondary factor that determines whether the intended referent is within the controllable domain of the speaker or not. In the next section, in order to unfold the discussion, it will be taken a look at the notion of controllability originally proposed by Balpinar (2012), which conditions the distribution of the non-anaphoric demonstratives in the discourse.

\section{Controllable Domain and the Usage of $b u$ and $o^{4}$}

Balpinar (2012) deals with the endophoric usages of the non-anaphoric $b u$ and $o^{5}$, and proposes that when the referent noun in the preceding sentence (= antecedent noun) is repeatedly used in the bu/o + noun phrase in the subsequent sentence, (a) whether the referent is psychologically/spatially close to the speaker cannot be associated with the endophoric use of the demonstratives, and (b) whether the referent is within the controllable domain of the speaker plays a major role in determining the distribution of the non-anaphoric bu/o. These properties can be seen in the following examples.

(1) (The speaker works hard using his both hands, and asks his colleague beside him to do a favor for him)

$\begin{array}{lll}\text { Ön-üm-deki } & \text { panel-de } & \text { kırmızı bir düğme } \\ \text { front-1SG.POSS-NML } & \text { panel-LOC } & \text { red a button }\end{array}$

by means of using a sound or specific writing method. See Balpinar (2012: 104) regarding the consequences induced by these two different definitions.

4 This section is a brief version of a part of my analysis in Balpinar (2012).

5 Balpinar (2012) reports that şu does not have endophoric (non-anaphoric/anaphoric) usages and it has only exophoric usages (cf. also Kinsui et al. 2002: 241). 
var ya. $\left\{{ }^{*}\right.$ bu/o $\}$ düğme-ye bas-ar mi-sin?

existent FIN DEM button-DAT push-AOR Q-2SG

'You know there is a red button on the panel in front of me. Would you push

that button?' (Balpinar 2012: 101)

In (1), the intended referent kırmızı düğme 'red button' cannot be marked by bu. According to the previous accounts (Hayasi, 1985, 1989; Nishioka, 2006), the demonstrative bu should be used to refer to the referent because it is relatively close to the speaker. However, only the use of $o$ is acceptable in this case. This raises the question of why $b u$ is not used in a case like (1). One possible answer is that the speaker is within the situation where he is unable to push the button, since he cannot release his hands from the work he already deals with (because it might be dangerous). That is, the referent in question may be assumed within the domain where the free physical act of the speaker (e.g. push the button) is restricted.

By contrast with the case in (1), the demonstrative $b u$ is used to refer to the entity düğme 'button' in the following (2).

(2) (The speaker explains some features of the car to the hearer)

Direksiyon-un üzer-in-deki düğme-yi gör-üyor

wheel-GEN surface-3SG.POSS-NML button-ACC see-PRES

mu-sun? $\left\{\mathrm{bu} /{ }^{*} \mathrm{o}\right\}$ düğme araba-nın hiz-ın-1 sabitle-r.

Q-2SG DEM button car-GEN speed-3SG.POSS-ACC limit-AOR

'Do you see the button on the wheel? This button limits the speed of the car.'

(Adapted from Balpinar 2012: 102)

In (2), the referent can be considered within the domain where the speaker's physical act (push the button) is not restricted in that the speaker can freely control it by his own will.

On the basis of these observations, Balpinar (2012: 102; 2019: 30) refers "a domain/sphere in which the speaker presupposes that his/her free (subjective) act of reference is not prevented at the time and place of the utterance" as controllable domain, and emphasizes the following points regarding the distribution of the non-anaphoric demonstratives $b u$ and $o$ :

(1) The non-anaphoric $b u$ is used to refer to the referent that is within the controllable domain of the speaker.

(2) The non-anaphoric $o$ is used to refer to the referent that is not within the controllable domain of the speaker.

Note that these properties are also functional when the intended referent is not physically present into the locality of the utterance. Consider the following examples.

(3) a. Yarın bir mektup yaz-acağ-1m. $\left\{b u /{ }^{*} \mathrm{o}\right\}$ mektub-u

tomorrow a letter write-FUT-1SG DEM letter-ACC

müdürbey-e ilet-ir-se-niz sevin-ir-im.

Director-DAT give-AOR-COND-2PL be.pleased-AOR-1SG

'Tomorrow I will write a letter. I would be pleased if you give

that letter to the director.'

b. Yarın bir mektup yaz-ınız ve $\left\{{ }^{*} b u / o\right\}$ mektub-u

tomorrow a letter write-2PL and DEM letter-ACC 
müdürbey-e ilet-iniz.

director-DAT give-2PL

'(You) write a letter and give that letter/it to the director.'

(Both 3a and 3b have been adapted from Hayasi 2004: 61 with a slight modification)

The referent mektup 'letter' in (3a-b) does not physically exist in the surrounding situation. In (3a), it can be considered that the speaker freely reflects his/her own idea to the content of the letter because the act of writing letter is performed by the speaker him/herself. In this sense, one can assume that the referent mektup 'letter' in (3a) is under subjective control of the speaker him/herself. In contrast, in (3b), the speaker cannot reflect his/her idea to the act of writing a letter because the person who writes the letter is the hearer. This indicates that the referent in $(3 b)$ is not within the controllable domain of the speaker. If these accounts are correct, our analysis predicts that $b u$ is selected in (3a) according to the generalization in (1) and $o$ is used in (3b) according to the generalization in (2). As can be seen in (3a) and (3b), only $b u$ in $(3 \mathrm{a})$ and $o$ in $(3 \mathrm{~b})$ are acceptable.

So far, we have seen that the concept of controllable domain is operative in determining the distribution of the non-anaphoric demonstratives $b u$ and $o$ in the discourse. In the following section, we will see that Turkish has a phenomenon which cannot be purely explained in terms of this concept, and show that there are some limiting conditions determining the distribution of the non-anaphoric demonstratives other than this parameter in Turkish demonstrative use.

\section{Some Other Factors Determining the Distribution of $b u$ and $o$}

Balpinar $(2011,2019)$ reports that the controllable domain is not only operative when the antecedent noun is one and the same with the co-referential noun (= the noun occurring in the bu/o + noun phrase in the subsequent sentence) (e.g. 4a), but also operative when the antecedent noun is synonymous with the co-referential noun (e.g. $4 \mathrm{~b}){ }^{6}$

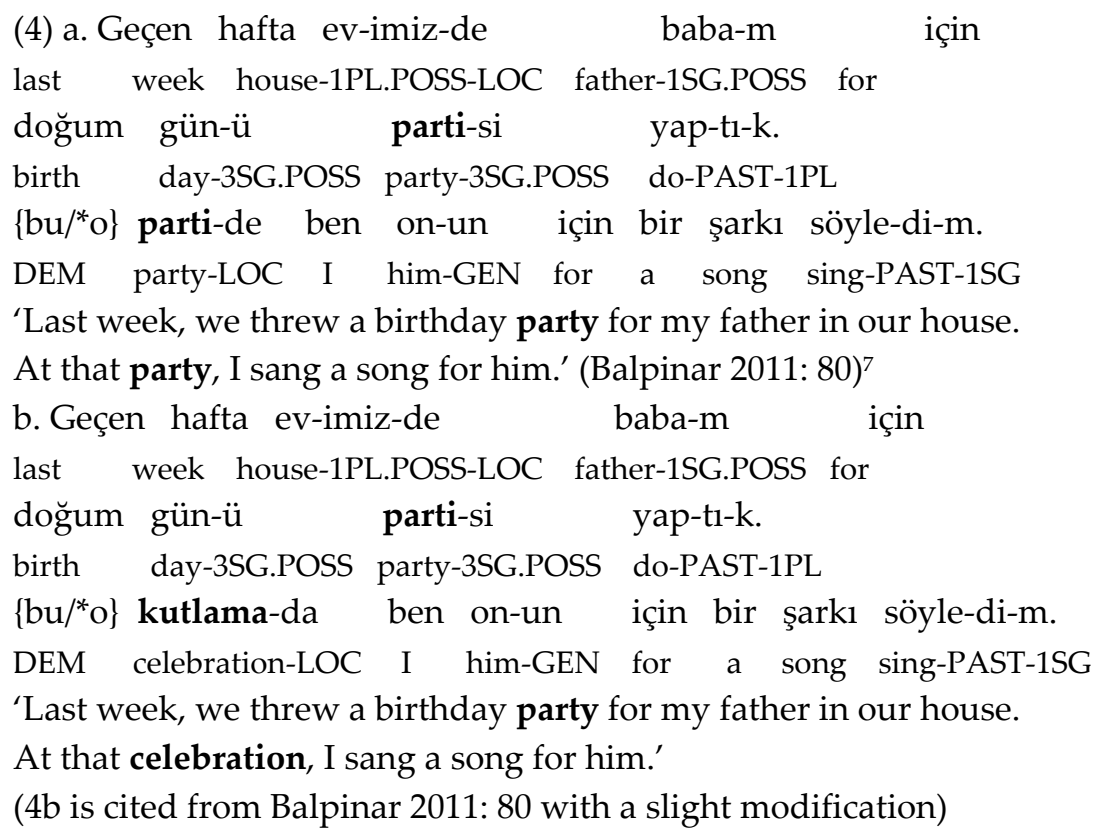

In Balpinar $(2011,2019)$, there is no further argument concerning this claim.

At the stage of collection of data to be analyzed, it has been cared to cite from various sources as much as possible. In addition, the fact that this article is a continuation of the author's 2012 study (Balpinar 2012) made it also necessary to include examples from the study in the data analysis. 
The demonstrative usage such as in $(4 \mathrm{~b})$ can be treated as an instance of the nonanaphoric use which is a subtype of the endophoric use in that the co-referential noun (kutlama 'celebration') occurring within the $b u+$ noun phrase can be associated with the antecedent noun (parti 'party') in the preceding sentence. That is, the antecedent of the $b u+$ noun phrase is already introduced into the preceding verbal text. In this sense, according to the conception mentioned in section 2, the distribution of the demonstratives must be determined by the concept of controllable domain. Specifically, the referent in (4a-b) is within the domain where it is directly experienced by the speaker, and therefore it can be assumed that the intended referent is under subjective control of the speaker him/herself. If this account is correct, according to the generalization (1) and (2) in section 2, it is expected that $b u$ is selected in (4a-b) to refer to the referent. Indeed, as seen in $(4 a-b), b u$ is used to refer to the referent. This shows that the distribution of the non-anaphoric demonstratives may even be determined by the concept of controllability such as in (4b). However, note that there are conditions other than this concept, which specify the appropriate usages of $b u$ and $o$. Let us consider the sentence in $\left(4 \mathrm{~b}^{\prime}\right)$.

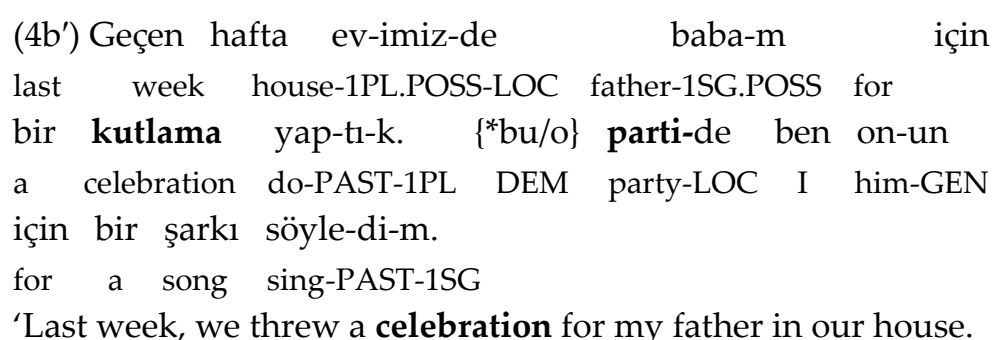

At that party, I sang a song for him.'

As can be easily seen in (4b) and $\left(4 b^{\prime}\right)$, the situation of the utterance in $\left(4 b^{\prime}\right)$ is akin to the one in $(4 b)$. The only difference between $(4 b)$ and $\left(4 b^{\prime}\right)$ is that the noun parti 'party' precedes the noun kutlama 'celebration' in the former, and the referent kutlama 'celebration' precedes the noun parti 'party' in the latter. In this regard, $\left(4 b^{\prime}\right)$ can be seen as a non-anaphoric variant of (4b). If this is correct, and all else being equal, the notion controllability must work as seen in (4b) and $b u$ must be selected to refer to the referent in $\left(4 b^{\prime}\right)$ because as mentioned above (the speaker assumes that) the intended referent is within the controllable domain of the speaker. However, the usage of $o$ is only acceptable in $\left(4 b^{\prime}\right)$. This indicates that the appropriate usages of the non-anaphoric demonstratives $b u$ and $o$ show sensitivity to the replaceability between the antecedent noun and the co-referential noun. This phenomenon can also be seen in the following sentences.

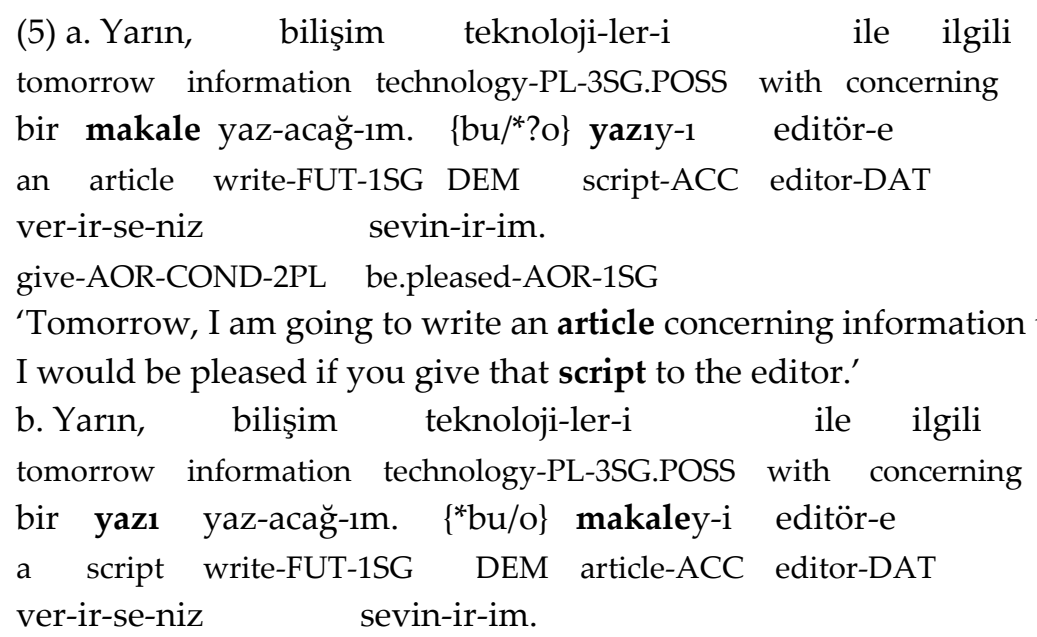


give-AOR-COND-2PL be.pleased-AOR-1SG

'Tomorrow, I am going to write a script concerning information technologies.

I would be pleased if you give that article to the editor.'

In (5a-b), the speaker can freely reflect his/her own will to the content of the article/script in question, since he/she performs the act of writing an article by him/herself. The referents in (5a-b) can be considered within the controllable domain of the speaker from this point of view. If this remark is correct, then $b u$ must be a reasonable option for both (5a) and (5b) according to the conditions (1) and (2) in section 2. In (5a), as we have expected, the intended referent can be marked by the demonstrative $b u$. In contrast, the usage of $b u$ in $(5 b)$ is not acceptable, and the only option to indicate the referent is the demonstrative $o$. This shows, as seen in (4b) and $\left(4 \mathrm{~b}^{\prime}\right)$, that the order of precedence between the antecedent noun and the co-referential noun plays a major role in determining the appropriate usage of the non-anaphoric bu/o (e.g. $4 \mathrm{~b}^{\prime}$ and $5 \mathrm{~b}$ ) as well as the concept of controllable domain. If this remark is correct, how can we make sense out of the following phenomena in which the interchangeability between the antecedent noun and the co-referential noun is possible?

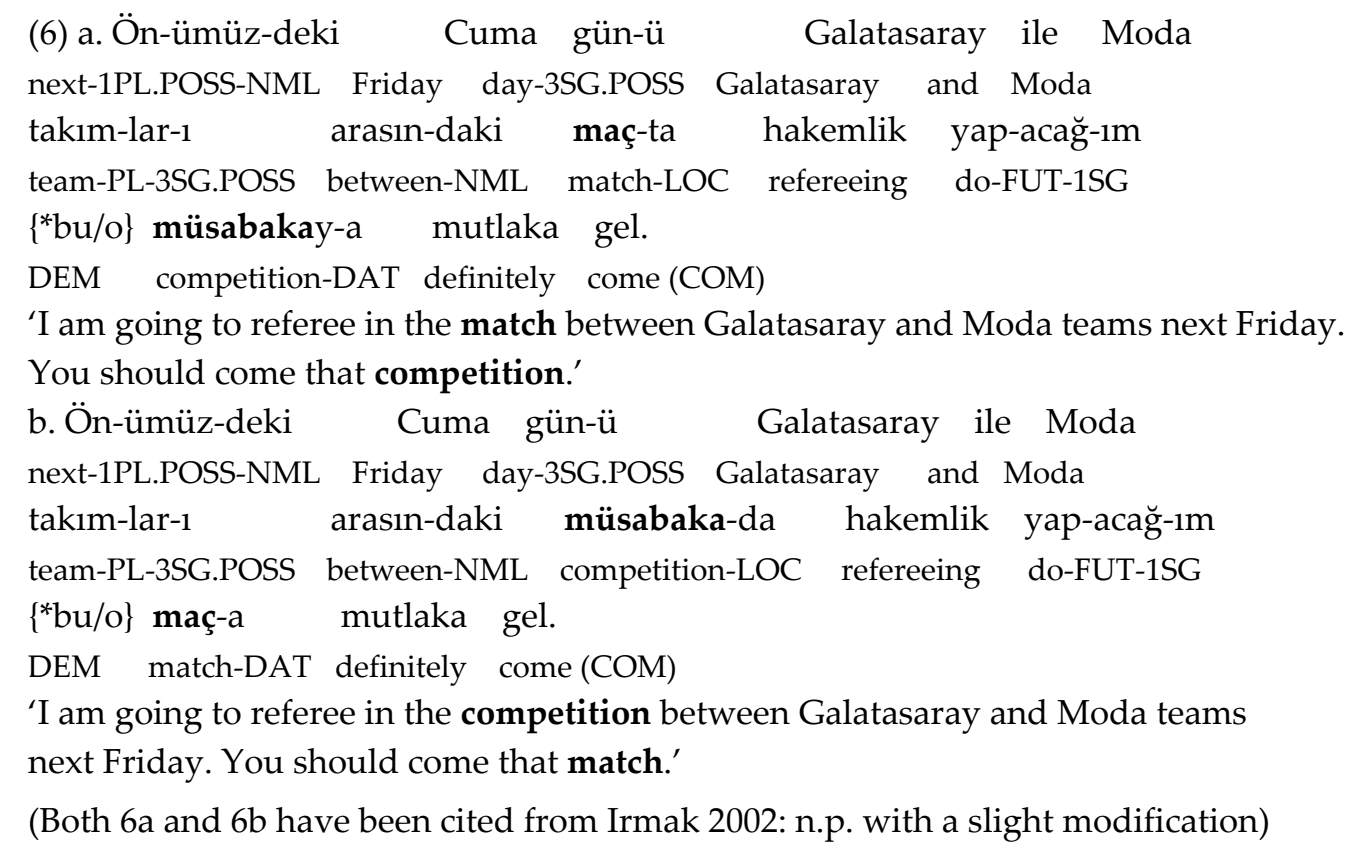

In $(6 a-b)$, it seems that the distribution of the non-anaphoric demonstratives is not sensitive to replaceability between maç 'match' and müsabaka 'competition' unlike the case seen in $\left(4 b-b^{\prime} / 5 a-b\right)$. This remark raises the question of what is the underlying reason of this phenomenon. One possible answer is that the referent in $\left(4 b-b^{\prime} / 5 a-b\right)$ is within the controllable domain of the speaker while the one in (6a-b) is not. More specifically, the referent in $(6 a-b)$ (match/competition) is a future event that has not realized yet, and also its progress or result is not under subjective control of the speaker him/herself. In this respect, it plausible to assume that it is not within the controllable domain of the speaker. Note that this analysis raises the another question of why the intended referent in $\left(4 \mathrm{~b}^{\prime} / 5 \mathrm{~b}\right)$ is marked by the demonstrative $o$ although it is within the controllable domain of the speaker. In order to find the answer of this question, we must focus on the semantic relation between the antecedent noun and the coreferential noun. When we take a closer look at the referents in $\left(4 b^{\prime}\right)$ and $(5 b)$, we can see that the antecedent noun kutlama $\left(4 \mathrm{~b}^{\prime}\right)$ semantically contains the co-referential noun parti, and the antecedent yazı in (5b) semantically contains the co-referential makale in (5b). Based on this 
observation, one can make the following generalization concerning the distribution of the nonanaphoric demonstratives $b u$ and $o$, where the speaker assumes the intended referent to be within the controllable domain:

(7) Mark the intended referent using the non-anaphoric demonstrative $o$ if and only if the antecedent noun semantically contains the co-referential noun, otherwise mark the referent using the non-anaphoric demonstrative $b u$.

The condition in (7) entails that in the non-anaphoric usage of the demonstratives, if there is a ' $x$ is a $y$ ' relation between the co-referential noun $(x)$ and the antecedent noun (y) (i.e. $y$ semantically contains $x$; e.g. $\left.4 b^{\prime} / 5 b\right)$, the intended object must be marked by the non-anaphoric demonstrative $o$; if there is a ' $y$ is a $x^{\prime}$ relation (i.e. $x$ contains $y$; e.g. $4 \mathrm{~b}^{\prime} / 5 \mathrm{a}$ ) or ' $y$ is the same as $x^{\prime}$ relation (e.g. 1-3, 4a) between $x$ and $y$, the referent must be marked by the demonstrative form bu.

So far, we have seen that (i) the distribution of the non-anaphoric demonstratives shows sensitivity to the interchangeability between the antecedent noun and the co-referential noun only when the referent is within the controllable domain of the speaker (e.g. $\left.4 b-b^{\prime} / 5 a-b\right)$, and (ii) the distribution of the non-anaphoric demonstratives is not sensitive to the interchangeability between the antecedent noun and the co-referential noun when the referent is not within the controllable domain of the speaker (e.g. 6a-b). In the light of these accounts and the analysis in section 2, it is possible to schematize the appropriate usages of the non-anaphoric demonstratives $b u$ and $o$ as in Figure 1.

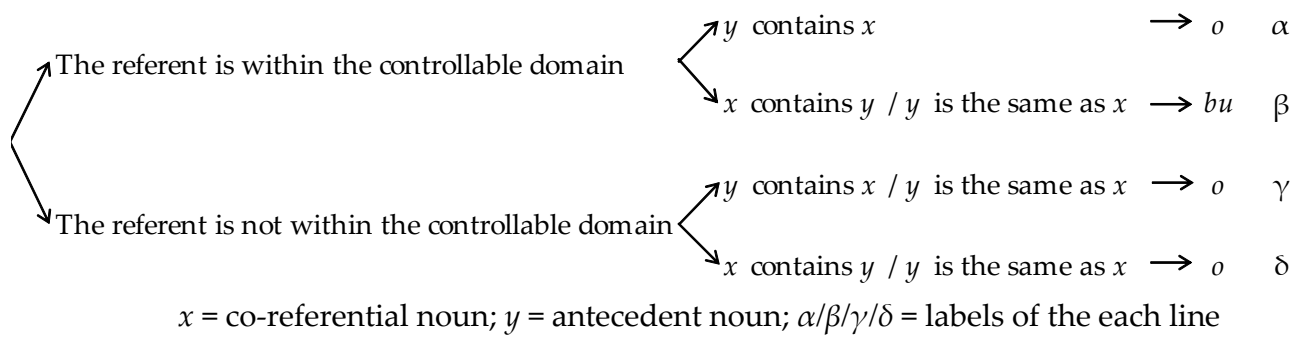

Figure 1. The distribution of the non-anaphoric demonstratives in Turkish

In this flowchart, according to the line in $\alpha$, the non-anaphoric form $o$ is used to refer to the referent if it is within the controllable domain of the speaker and the antecedent noun semantically contains the co-referential noun (e.g. $4 b^{\prime} / 5 b$ ); as for the case in $\beta, b u$ refers to the object if it is within the controllable domain and the co-referential noun semantically covers the antecedent noun (e.g. $4 \mathrm{~b}$ ) or the co-referential noun is the one and the same with the antecedent noun (e.g. 1-4a); according the cases in $\gamma$ and $\delta, o$ indicates the entity if it is outside of the controllable domain of the speaker and the antecedent noun semantically contains the coreferential noun or vice versa (e.g. 6a-b) or the co-referential noun is the one and the same with the antecedent noun (e.g. 1/3b).

Finally, I would like to mention about temporal factors that play an immensely important role in determining whether the intended referent is within the controllable domain or not. Let us turn our attention to the demonstrative usages in (6a-b) again. In this example, we have seen that the referent (match or competition) is a future event that has not realized yet, and we have assumed that its progress or result is not under subjective control of the speaker him/herself. In this regard, one may consider that the referent is controllable or not is related to the time of the event in which that referent occurs. Note, however, that this does not mean that a referent which is a part of an event in the future/past unconditionally belongs to the domain that is 
outside of the controllable domain. Although there is an entity which is clearly associated with a future/past event, that entity can be assumed to be within the controllable domain of the speaker when the speaker has a subjective stance (physicological affinity) or control regarding the entity in question. Consider the following sentences.

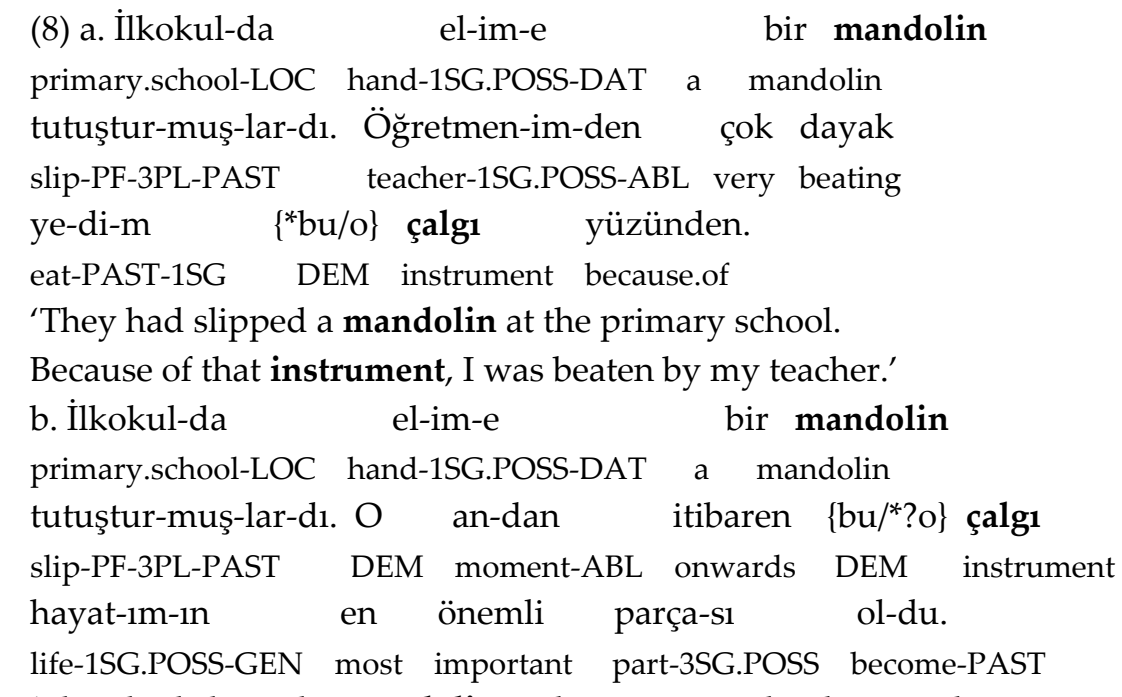

'They had slipped a mandolin at the primary school. From that time, that instrument has become the most important part of my life.'

(Both 8a and 8b have been adapted from Baydur 2009: 847 with a slight modification)

The speaker assumes that the referent çalgı 'instrument'/mandolin 'mandolin' in (8a) is not within his/her controllable domain while the same referent in (8b) is under control of him/herself although it is a part of the past event experienced by the speaker: In the former, the instrument denotes an object that reminds the speaker his/her unpleasant memories in the past; in the latter, on the other hand, the same object is indispensable for the speaker's daily life. If this account is correct, we can say that $o$ is selected to refer to the object in (8a) according to the case $\delta$ and $b u$ is selected to indicate the same object in (8b) according to the case $\beta$ in Figure 1. As can be seen in (8a-b), solely $o$ in (8a) and $b u$ in (8b) is acceptable. These remarks suggest that temporal dimension is a secondary factor in determining whether the entity is within the controllable domain of the speaker or not.

\section{Conclusions}

In Balpinar (2012), it has been shown that the concept of controllable domain plays important role in determining the appropriate usages of the non-anaphoric demonstratives $b u$ and $o$. In this study, it has been indicated that there is a phenomenon in Turkish demonstratives, which cannot only be dealt with this concept, and proposed that the interchangeability between the antecedent noun and the co-referential noun also plays major role in conditioning the distribution of the demonstratives bu/o. Among others, the following points are discussed in the text: 1) on the situation where the intended referent is within the controllable domain of the speaker, $b u$ is used to refer to it if the co-referential noun semantically contains the antecedent noun, $o$ is used to refer to it if the antecedent noun semantically contains the co-referential noun, 2) on the situation where the referent is not within the controllable domain of the speaker, $o$ refers to it regardless of whether the co-referential noun semantically contains the antecedent noun or not, 3) temporal dimension is a secondary factor in determining whether the referent is within the controllable domain of the speaker or not. Such analysis on the non-anaphoric demonstratives $b u$ and $o$ are significant in that they 
shed light on the semantic parameters which determine the occurrence of them in the universe of discourse, and in that its findings provide a more comprehensive view on understanding the demonstrative system of Turkish.

\section{Abbreviations}

1, 2, 3: first, second and third person, ABL: ablative; ACC: accusative; AOR: aorist; COM: comitative; COND: conditional; DAT: dative; DEM: demonstrative; FIN: final sentence enclitic; FUT: future; GEN: genitive; LOC: locative; NML: nominalization; PAST: past; PF: perfective; PL: plural; POSS: possessive; PRES: present; Q: interrogative particle; SG: singular

\section{Acknowledgment}

I would like to thank Semih Akyol, Nilgun Guler, and Necmettin Erdogan for acceptability judgments of the Turkish demonstrative examples used in this paper. All remaining errors are, of course, my own. 


\section{REFERENCES}

BALPINAR, Metin (2011), “Torukogo shijishi no bunmyaku shiji yōhō ni tsuite: Bunshōōkei toshite no $b u, o$ no yōhō" [On the the text dependent use of Turkish demonstratives: the usage of $b u$ and $o$ as sentence anaphor]. Kyōto Daigaku Gengogaku Kenkyū, 30: 71-105.

BALPINAR, Metin (2012), “Torukogo shijishi ni okeru hibunmyaku shiji yōhō to bunmyaku shiji yōhō ni tsuite: bunmyaku shiji yōhō wo chūshin ni" [On non-text and text dependent uses of Turkish demonstratives: focusing on text dependent use]. Ajia \& Afurika Gengo Bunka Kenkyū, 83: 89-116.

BALPINAR, Metin (2014), “Torukogo shijishi ni okeru hibunmyaku shiji yōhō no saikentō" [Re-examination of the non-text dependent use of Turkish demonstratives]. Tōkyō Daigaku Gengogaku Ronshū, 35: 21-39.

BALPINAR, Metin (2019), Demonstratives and Grammaticalization: A Perspective from Modern Turkish, London and New York: Routledge.

BANGUOĞLU, Tahsin (2004), Türkçe'nin Grameri, Ankara: Türk Dil Kurumu.

BASTUJI, Jacqueline (1976), Les Relations Spatiales en Turc Contemporain; Étude Sémantique. Paris: Éditions Klincksieck.

BAYDUR, Memet (2009), Tiyatro Oyunları, İstanbul: İletişim Yayınları.

ERGİN, Muharrem (1958), Türk Dil Bilgisi, İstanbul: İstanbul Üniversitesi Edebiyat Fakültesi Yayınları.

GENCAN, Tahir Nejat (2001), Dilbilgisi, Ankara: Türk Dil Kurumu.

GÖKSEL, Aslı - KERSLAKE, Celia (2005), Turkish: A Comprehensive Grammar, London and New York: Routledge.

HAYASI, Tōru (1985), “Torukogo no shijishi” [Turkish demonstratives]. Ajia \& Afurika Gengo Bunka Kenkyūjo Tsūshin, 53: 55-57.

HAYASI, Tōru (1989), “Torukogo no susume 3: 'kore-sore-are' are kore” [An invitation to Turkish 3: 'kore, sore, are' are kore]. Gengo, 18.1: 96-101.

HAYASI, Tōru (2004), “Türkçe ve Japonca İşaret Sözcükleri Üzerine Bir Deneme”. Dilbilim Araştırmaları, 2004: 51-62.

HAYASI, Tōru (2008), “Torukogo shijishi şu no tokuchō" [Characteristics of the Turkish demonstrative şu]. Tōkyō Daigaku Gengogaku Ronshū, 27: 217-232.

HAYASI, Tōru (2009), "Torukogo shijishi no sentaku ni okeru washa no handan no baratsuki" [How variant are the judgments of Turkish speakers on the usage of demonstratives?]. Tōkyō Daigaku Gengogaku Ronshū, 28: 267-282.

HAYASI, Tōru (2014), "Temporal characteristic of the Turkish demonstrative şu," Turcology and Linguistics: Éva Ágnes Csató Festschrift, Nurettin Demir, Birsel Karakoç, Astrid Menz (Eds.). Ankara: Hacettepe Üniversitesi: 209-218.

IINUMA, Eizō. (1995), Torukogo Kiso [Basic Turkish], Tōkyō: Besutosha.

IRMAK, Coşkun (2002), Siyah Çoraplılar. İstanbul: Mitos Boyut Yayınları.

JANSKY, Herbert (1943), Lehrbuch der Türkischen Sprache, Wiesbaden: Otto Harrassowitz.

KINSUI, Satoshi - et al. (2002), "Shijigo no rekishiteki-taishō gengogakuteki kenkyū: Nihongo-KankokugoTorukogo" [Historical and comparative linguistic studies of demonstrative words: Japanese, Korean, Turkish], Shirizzu Gengo Kagaku 4 Taishō Gengogaku [Series in linguistic science 4 contrastive linguistics], Naoki Ogoshi (Ed.). Tōkyō: Tōkyō daigaku shuppankai: 217-247.

KORKMAZ, Zeynep (2009), Türkiye Türkçesi Grameri: Şekil Bilgisi, Ankara: Türk Dil Kurumu.

KORNFILT, Jaklin (1997), Turkish, London: Routledge.

LEWIS, Geoffrey L. (1967), Turkish Grammar, Oxford: Oxford University Press.

NISHIOKA, Izumi (2006), Gendai Churuku shogo no shijishi no kenkyū [A study on demonstratives in modern Turkic languages], Fukuoka-Japan: Kyūshū University (unpublished doctoral dissertation).

ÖZYÜREK, Aslı (1998), "An analysis of the basic meaning of Turkish demonstratives in face-to-face conversational interaction," Oralité et Géstualité: Communication multimodale, interaction, Serge Santi, Isabelle Guaïtella, Christian Cavé, Gabrielle Konopczynski (Eds.). Paris: L'Harmattan: 609-614.

PETERS, Ludwig (1947), Grammatik der Türkischen Sprache, Berlin: Axel Juncker Verlag.

SWIFT, Lloyd B. (1963), A Reference Grammar of Modern Turkish, Bloomington: Indiana University.

UNDERHILL, Robert (1976), Turkish Grammar, Cambridge: The MIT Press. 